\title{
GROWTH AND NUTRIENT COMPOSITION OF INDIAN SPINACH GROWN IN SALINE SOIL USING TREATED WATER
}

\author{
FARZANA YASMIN ${ }^{1 *}$, SAYMA KHANOM AND SHAHID AKHTAR HOSSAIN \\ Department of Soil, Water and Environment, University of Dhaka, Dhaka-1000, Bangladesh \\ ${ }^{1}$ Center for Advanced Research in Sciences, University of Dhaka, Dhaka-1000, Bangladesh
}

\begin{abstract}
A field experiment was conducted in Batiaghata Upazila of Khulna district to evaluate the growth and nutrient composition on Indian spinach by irrigating with different water sources. Water that has been used as treatment are saline- and treated water (water from a project called Managed Aquifer Recharge (MAR)). A field condition was also included (control). As per consumption pattern of Indian spinach, leaf and stem are mixed together. All the growth parameters of the crop were significantly improved for treated water except for the plant height. Carbohydrate, protein, fat, total dietary fiber (TDF) and energy increased $(1.06,2.76,0.15,3.21 \mathrm{~g} / 100 \mathrm{~g}$ and $23.09 \mathrm{Kcal} / 100 \mathrm{~g})$ with treated water than the control and saline water while ash content $(2.04 \mathrm{~g} / 100 \mathrm{~g})$ decreased than saline water. $\mathrm{pH}, \mathrm{EC}, \mathrm{Na}, \mathrm{K}, \mathrm{S}, \mathrm{Fe}$ and $\mathrm{Mg}$ of the soil decreased markedly by applying treated water and other nutrients present in soil also varied. From the study, it is revealed that the best alternate source of water for irrigation is MAR water which can improve plant nutrient content and uptake and soil nutrient status.
\end{abstract}

Key words: Managed aquifer recharge, Saline water, Nutrient composition, Indian spinach

\section{Introduction}

One of the primary objectives of agriculture is to provide the food and fiber needs of human beings which increase as the population increases. Irrigation with saline water is the major agricultural problem in the coastal region of Bangladesh which causes reduced crop yields and income of the coastal population. The intrusion of saline water on coastal land is affecting adversely on the crops production, supply of drinking water and industrial water. The increased intrusion of saline water into the fresh water of southwest Bangladesh is one of the most significant effects on the aquatic environment as well as on environment (Karim et al. 1990), which changed the overall ecosystem in the coastal areas of the region. About 0.282, 0.297, 0.191, 0.450 and 0.087 million hectares of lands are affected by very slight, slight, moderate, strong and very strong salinity, respectively (Haque 2006). This varying salinity levels have been affecting the cropping pattern and yield potential. In some coastal places, lack of nutritionally rich foods along with the consumption of higher minerals content of food due to salinity are causing significant health problems. Salinity in soil restricts the production of many of leafy and non-leafy vegetables and if dark leafy green vegetables can be grown in saline areas, it can supply proper nutrition to the poor and rural people. Managed Aquifer Recharge (MAR) for

*Author for correspondence: <fyasmin_08@du.ac.bd>. 
Community water supply in saline areas is a project that supply drinking water to the people in the coastal regions by mainly rain water harvesting in association with Department of Public Health Engineering (DPHE), Department of Geology, University of Dhaka, Acacia Water, Netherlands and local nongovernmental organizations (Web 1). Here, water was collected from the nearby pond and rain water harvested from rooftop and pumped into 4 infiltration wells to a depth of $60 \mathrm{ft}$. A three layer filter was used and on top of which dense jute canvas was used. After filtration the salinity of water was markedly reduced.

The present study was undertaken to observe the visible differences and nutritional composition of vegetable for irrigation with saline and MAR water and also to identify whether it is possible to grow salt sensitive crops particularly vegetables by irrigating with water from MAR system as an alternate source in coastal areas.

\section{Materials and Methods}

The field experiment was set up at Gangarampur union of Batiaghata Upazila in Khulna district, Bangladesh. The geographic location of the Gangarampur is $22^{\circ} 40.7091 \mathrm{~N}$ and 89³0.245E (Fig. 1).

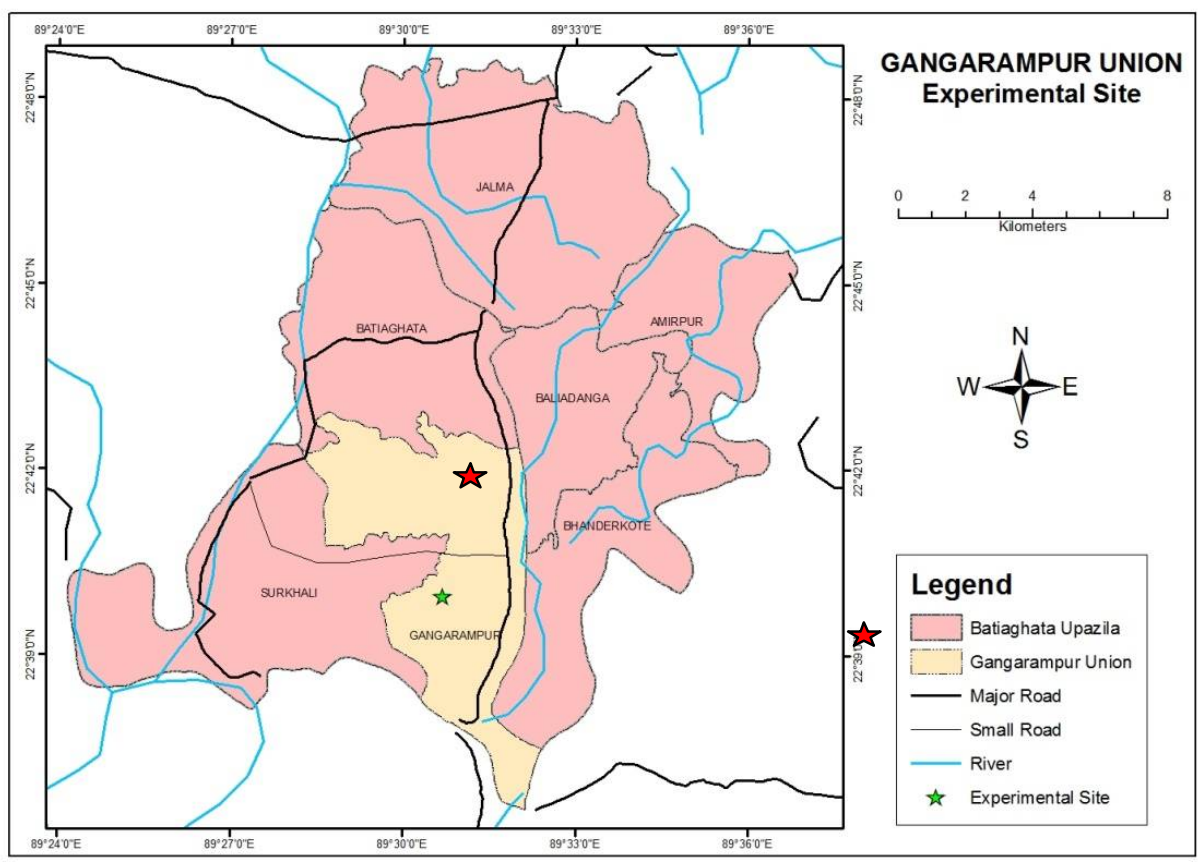

Fig. 1. Experimental site location (Source: GIS Laboratory, Department of Soil, Water and Environment, University of Dhaka). 
Initial soil analysis by standard methods showed that the experimental field soil has a $\mathrm{pH}$ of 7.4, EC of $0.215 \mathrm{dS} / \mathrm{m}$ and contains $90 \mathrm{mg} / \mathrm{kg}$ available $\mathrm{N}$ with $1.09 \%$ organic carbon, $16 \mathrm{mg} / \mathrm{kg}$ available $\mathrm{P}, 7.36 \%$ available $\mathrm{K}, 0.16 \%$ available $\mathrm{S}, 12.86 \% \mathrm{Na}, 8.28 \% \mathrm{Ca}$ and $0.78 \% \mathrm{Mg}$. Surface soil was collected from $0-15 \mathrm{~cm}$ and sub-surface soil was collected from $15-30 \mathrm{~cm}$.

The experiment was laid out in CBD with 3 replications i.e., whole experimental area was divided into 3 blocks, each block representing 1 replication. Unit plot size was $2.0 \mathrm{~m}$ $\times 2.0 \mathrm{~m}$ and space between the plots, blocks and around the field was $1 \mathrm{~m}$. Total unit plot was 9 and total experimental area was $10 \mathrm{~m} \times 10 \mathrm{~m}$.

Two types of water treatments were used in the experiment. One was saline water, which has been collected from the tube-well and second one was the treated water, which has been collected from MAR. Another observation was made considering the field condition of the plots which was considered as control and no water was added from outside during the experiment in this treatment plot. Different physico-chemical properties of the treatment water were shown in Table 1.

Two treatments were distributed randomly in 6 plots of which 3 were used to observe field condition (control). At the beginning of the experiment, the land was well prepared before sowing seed and no fertilizer was applied. Seeds of Indian spinach were broadcast on 28 March, 2014. After one week of sowing, seeds germinated. Weeding and thinning were done as per requirement for the healthy growth of seedlings.

Table 1. Comparison of physico-chemical properties of control, saline and treated water.

\begin{tabular}{lllll}
\hline Properties & $\begin{array}{l}\text { Control } \\
\text { water }\end{array}$ & $\begin{array}{l}\text { Saline } \\
\text { water }\end{array}$ & $\begin{array}{l}\text { Treated } \\
\text { water }\end{array}$ & $\begin{array}{l}\text { Combined } \\
\text { Sd } \pm \text { error }\end{array}$ \\
\hline $\mathrm{pH}$ & $6.2 \pm 0.10$ & $7.8 \pm 0.04$ & $7.6 \pm 0.14$ & $0.77 \pm 0.26$ \\
$\mathrm{EC}(\mathrm{dS} / \mathrm{m})$ & $0.102 \pm 0.002$ & $4.03 \pm 0.19$ & $1.07 \pm 0.02$ & $1.87 \pm 0.62$ \\
$\mathrm{Na}(\mathrm{mg} / \mathrm{l})$ & $3.68 \pm 0.05$ & $107.62 \pm 0.25$ & $89.39 \pm 0.03$ & $48.01 \pm 16.00$ \\
$\mathrm{~K}(\mathrm{mg} / \mathrm{l})$ & $0.24 \pm 0.02$ & $8.89 \pm 0.08$ & $13.29 \pm 0.38$ & $5.81 \pm 1.94$ \\
$\mathrm{Ca}(\mathrm{mg} / \mathrm{l})$ & $0.58 \pm 0.12$ & $54.05 \pm 0.08$ & $65.34 \pm 0.02$ & $29.95 \pm 9.98$ \\
$\mathrm{Mg}(\mathrm{mg} / \mathrm{l})$ & $0 \pm 0$ & $30.04 \pm 0.34$ & $28.48 \pm 0.14$ & $14.58 \pm 4.86$ \\
$\mathrm{Fe}(\mathrm{mg} / \mathrm{l})$ & $0.2 \pm 0.08$ & $1.345 \pm 0.02$ & $0.135 \pm 0.008$ & $0.59 \pm 0.20$ \\
$\mathrm{Zn}(\mathrm{mg} / \mathrm{l})$ & $0.001 \pm 00$ & $0.199 \pm 0.007$ & $0.02 \pm 0.01$ & $0.10 \pm 0.03$ \\
$\mathrm{Cu}(\mathrm{mg} / \mathrm{l})$ & $0 \pm 0$ & $0 \pm 0$ & $0 \pm 0$ & $000 \pm 000$ \\
$\mathrm{Mn}(\mathrm{mg} / \mathrm{l})$ & $0.03 \pm 0.02$ & $0.203 \pm 0.005$ & $0.023 \pm 0.003$ & $0.09 \pm 0.03$ \\
\hline
\end{tabular}


The plots were properly watered as per treatment. Amount of water applied to each field was uniform. As the field experiment was based on water treatment, rain water was not allowed to fall or seep to the saline and treated water plots. So, each plot was surrounded with aluminum sheet of $15 \mathrm{~cm}$ height and placed all around the plots. A bamboo made rain shed was used which was covered with a polythene sheet during the rain.

The crop was harvested after 55 days of sowing. At the time of harvest, 5 plants from each plot was selected randomly and fresh weight of the plants, height, base diameter, dry weight of the plants were noted. Again, 20 plants were randomly collected from each plot and brought to the laboratory for analyzing nutrient composition and mineral content. The edible portion (leaf and stem) of plants were analyzed as per consumption pattern. Standard analytical methods were used to analyze soil and plant samples (Huq and Alam 2005). Nutrient compositions of the plants were analyzed as described by Raghuramulu et al. (2003). Statistical analysis (Mean \pm Sd, ANOVA) was done using SPSS (version 20).

\section{Results and Discussion}

Relative performances of growth and yield parameters such as plant height, base diameter, fresh and dry weight of Indian spinach cultivated in coastal area under various water salinity levels are presented in Fig. 2. Maximum plant height was observed with treated water $(33.6 \mathrm{~cm})$, while saline water showed lowest plant height $(23.5 \mathrm{~cm})$. Similarly the base diameter $(23.5 \mathrm{~cm})$, fresh weight $(31.7 \mathrm{~g})$ and dry matter $(6.0 \mathrm{~g})$ content were found higher in treated water compared to saline water and control fields. Lowest base diameter $(18.7 \mathrm{~mm})$ was recorded in control plants.

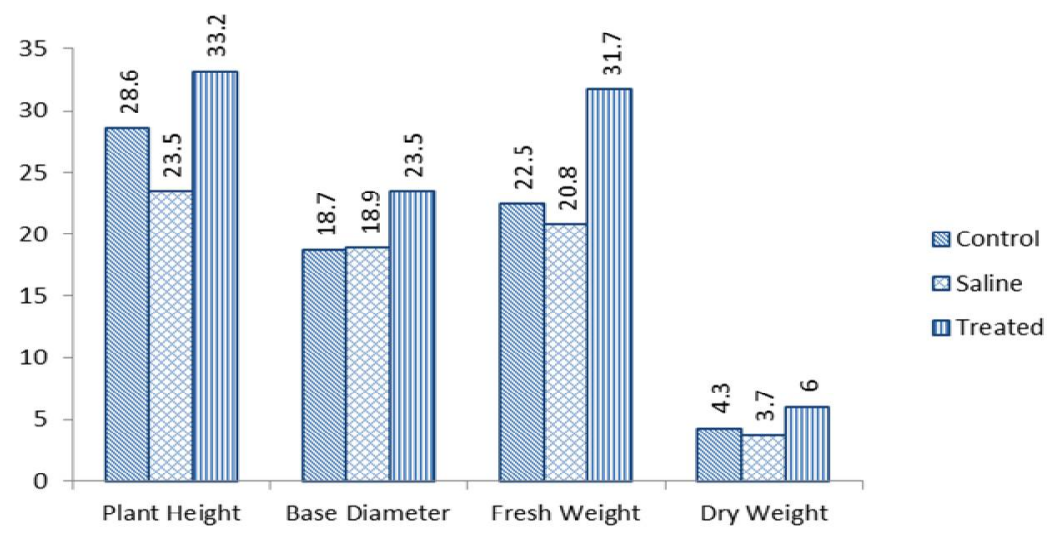

Fig. 2. Plant growth performance of Indian spinach in response to various irrigation water applications. 
The higher and lower values of plant height, base diameter, fresh and dry weight might be due to the variation of salt tolerance capacity of the plants, scarcity of rainfall during growing season and varying level of salinity in soil. A significant negative correlation was found between soil salinity and base diameter, fresh weight and dry weight $(\mathrm{p}<$ 0.01) that is, base diameter, fresh weight and dry weight of the plant increases with decreasing salinity. Plant height also showed negative influences with soil salinity. Francois et al. (1990) reported that growth of two guar plant cultivars was reduced and increasing levels of salinity caused disorder of photosynthate distribution. Higher concentration of brackish water greatly reduced the biomass production of peanut (Chavan and Karadge 1980). Faba beans and tomato cultivated using sea water containing higher $\mathrm{NaCl}$ produced less dry matter (Ullah et al. 1994).

Effect on nutrient composition: Irrigation with saline water had a pronounced effect on synthesis and accumulation of organic molecules in Indian spinach. Higher moisture content was recorded in the Indian spinach as $91.54 \mathrm{~g} / 100 \mathrm{~g}$, with saline irrigation water, $90.77 \mathrm{~g} / 100 \mathrm{~g}$, with treated water and $90.65 \mathrm{~g} / 100 \mathrm{~g}$ with control water (Table 2). This finding suggests that higher moisture content might be due to the presence of salt that expelled moisture in the soil and facilitate uptake by the plant. Similar moisture content was observed in Food Composition Table of Bangladesh (91.8 g/100 g) (FCTB 2013). In addition, the proximate analysis [protein content $(2.76 \mathrm{~g} / 100 \mathrm{~g})$, total fat content $(0.15$ $\mathrm{g} / 100 \mathrm{~g})$, dietary fiber content (TDF) $(3.21 \mathrm{~g} / 100 \mathrm{~g})$, available carbohydrate (1.06 $\mathrm{g} / 100 \mathrm{~g})$ and energy content $(23.09 \mathrm{Kcal} / 100 \mathrm{~g})]$ of the Indian spinach plant were recorded highest with treated water irrigation practices. On the contrary, these values were lowest (Protein $=2.29 \mathrm{~g} / 100 \mathrm{~g}$, fat $=0.08 \mathrm{~g} / 100 \mathrm{~g}$, TDF $=2.73 \mathrm{~g} / 100 \mathrm{~g}$, available carbohydrate $=0.83 \mathrm{~g} / 100 \mathrm{~g}$ and energy $=18.72 \mathrm{Kcal} / 100 \mathrm{~g}$ ) while saline water irrigation practices were done (Table 2). The ash content (2.52 to 2.02) g/100 g was found higher in saline water irrigation practices spinach than that of treated and control practices spinach (Table 2). Higher ash content in saline water irrigation practices spinach may indicate the higher salt accumulation in the plants (Katerji et al. 2005). Thus, it can be concluded that the protein, fat, available carbohydrate and energy content were found to be in the order:

Saline water $<$ control $<$ treated water

If the results are compared with standard food composition of Bangladesh, an increased content of protein, ash, TDF, moisture values and decreased content of fat, carbohydrates and energy content may be observed (Table 2, FCTB 2013). By irrigating with treated water, TDF, ash and energy of Indian spinach is found medium, compared to the other two treatments. But TDF and ash are higher than the standard value $(2.2 \mathrm{~g} / 100 \mathrm{~g}$ and 1.2 
Table 2. Nutrient composition of Indian spinach under different irrigation water applications.

\begin{tabular}{lccccccc}
\hline & \multicolumn{7}{c}{ Indian Spinach (leaf + stem) } \\
\cline { 2 - 8 } Treatment & $\begin{array}{c}\text { Moisture } \\
(\mathrm{g} / 100 \mathrm{~g})\end{array}$ & $\begin{array}{c}\text { Protein } \\
(\mathrm{g} / 100 \mathrm{~g})\end{array}$ & $\begin{array}{c}\text { Fat } \\
(\mathrm{g} / 100 \mathrm{~g})\end{array}$ & $\begin{array}{c}\text { Ash } \\
(\mathrm{g} / 100 \mathrm{~g})\end{array}$ & $\begin{array}{c}\text { TDF } \\
(\mathrm{g} / 100 \mathrm{~g})\end{array}$ & $\begin{array}{c}\text { Available } \\
\text { Carbohydrate } \\
(\mathrm{g} / 100 \mathrm{~g})\end{array}$ & $\begin{array}{c}\text { Energy } \\
(\mathrm{Kca} / 100 \mathrm{~g})\end{array}$ \\
\hline Control & 90.65 & 2.75 & 0.09 & 2.02 & 3.60 & 0.89 & 22.57 \\
Saline & 91.54 & 2.29 & 0.08 & 2.52 & 2.73 & 0.83 & 18.72 \\
Treated & 90.77 & 2.76 & 0.15 & 2.04 & 3.21 & 1.06 & 23.09 \\
$\mathrm{p}<0.05$ & 0.053 & 0.000 & 0.000 & 0.000 & 0.000 & $\mathrm{NS}$ & 0.021 \\
$\begin{array}{l}\text { FCTB } \\
\text { value }\end{array}$ & 91.8 & 2.4 & 0.3 & 1.2 & 2.2 & 2.1 & 25 \\
\hline
\end{tabular}

$\mathrm{g} / 100 \mathrm{~g})$ and energy is lower than the standard values $(25.0 \mathrm{~g} / 100 \mathrm{~g})$ (FCTB 2013). This variation in nutrient composition might be due to the variation of salt uptake by plants under different salinity conditions, plant physiology and salt stress condition (Rahneshan et al. 2017). The lower moisture content might be due to less rainfall during the plant growth periods and salt stress condition. In addition, some moisture might be lost during the transportation of plants from Khulna to Dhaka. The present findings are in conformity with Feizi et al. (2010).

Effect on mineral content: The mineral content ( $\mathrm{Na}, \mathrm{K}, \mathrm{Ca}, \mathrm{Mg}, \mathrm{Fe}, \mathrm{Zn}, \mathrm{Cu}, \mathrm{Mn})$ of the Indian spinach varied with the three different water treatments and has been compared with the mineral content recorded in the FCTB (2013).

The sodium (Na) content in the Indian spinach was 735.37, 1248.8 and $958.96 \mathrm{mg} / 100 \mathrm{~g}$ (Fig. 3). The standard value of $\mathrm{Na}$ is $69 \mathrm{mg} / 100 \mathrm{~g}$ (FCTB 2013). K, Ca and Mg content in the Indian spinach were also higher in saline water treatment $(2603.28,3772.5$ and $2868.92 \mathrm{mg} / 100 \mathrm{~g})$ than the treated water $(2496.06,2647.5$ and $440.18 \mathrm{mg} / 100 \mathrm{~g})$. The standard value of $\mathrm{K}, \mathrm{Ca}$ and $\mathrm{Mg}$ are 187, 111 and $179 \mathrm{mg} / 100 \mathrm{~g}$, respectively (FCTB 2013). So, it is observed that by irrigating with treated water, $K$ content has been decreased than the saline water but it is higher than the standard value.

It can be seen that by irrigating with treated water, $\mathrm{Na}$ and $\mathrm{Mg}$ content can be drastically reduced than the saline water treatments, although it is higher than the standard value. $\mathrm{Na}, \mathrm{K}$ and $\mathrm{Ca}$ contents have increased than the control water treatments but decreased than the saline water and have higher values than the standard one. Increasing the salinity of the irrigation water increased the concentration of both $\mathrm{Na}$ and $\mathrm{K}$ in the saturation extracts and greatly increased the accumulation of $\mathrm{Na}$ in leaves of wheat (Devitt et al. 1981). By irrigating with treated water, Mg content has decreased than the other two water treatments but it is still higher than the standard value. The iron $(\mathrm{Fe})$ 
content in the Indian spinach was 4.9, 5.34, and $1.86 \mathrm{mg} / 100 \mathrm{~g}$ in control, saline and treated water respectively, although standard value of Fe is $2.2 \mathrm{mg} / 100 \mathrm{~g}$ (FCTB 2013). So, it is found that by irrigating with treated water, Fe content has decreased than the other two water treatments and it is lower than the standard value. The $\mathrm{Na}^{+}, \mathrm{Fe}, \mathrm{Zn}$ and $\mathrm{Cu}$ contents significantly increased, while $\mathrm{K}^{+}, \mathrm{Ca}^{2+}, \mathrm{Mg}^{2+}$ and $\mathrm{Mn}$ contents decreased in high salinity levels and similar results were also found by Daryush et al. (2012).

The $\mathrm{Zn}$ and $\mathrm{Cu}$ contents in the Indian spinach were highest by irrigating with treated water treatment $(3.96$ and $1.87 \mathrm{mg} / 100 \mathrm{~g})$ and lowest by saline water irrigation (2.65 and $0.75 \mathrm{mg} / 100 \mathrm{~g}$ ) (Fig. 3). The standard value of $\mathrm{Zn}$ and $\mathrm{Cu}$ are 0.35 and $0.06 \mathrm{mg} / 100 \mathrm{~g}$
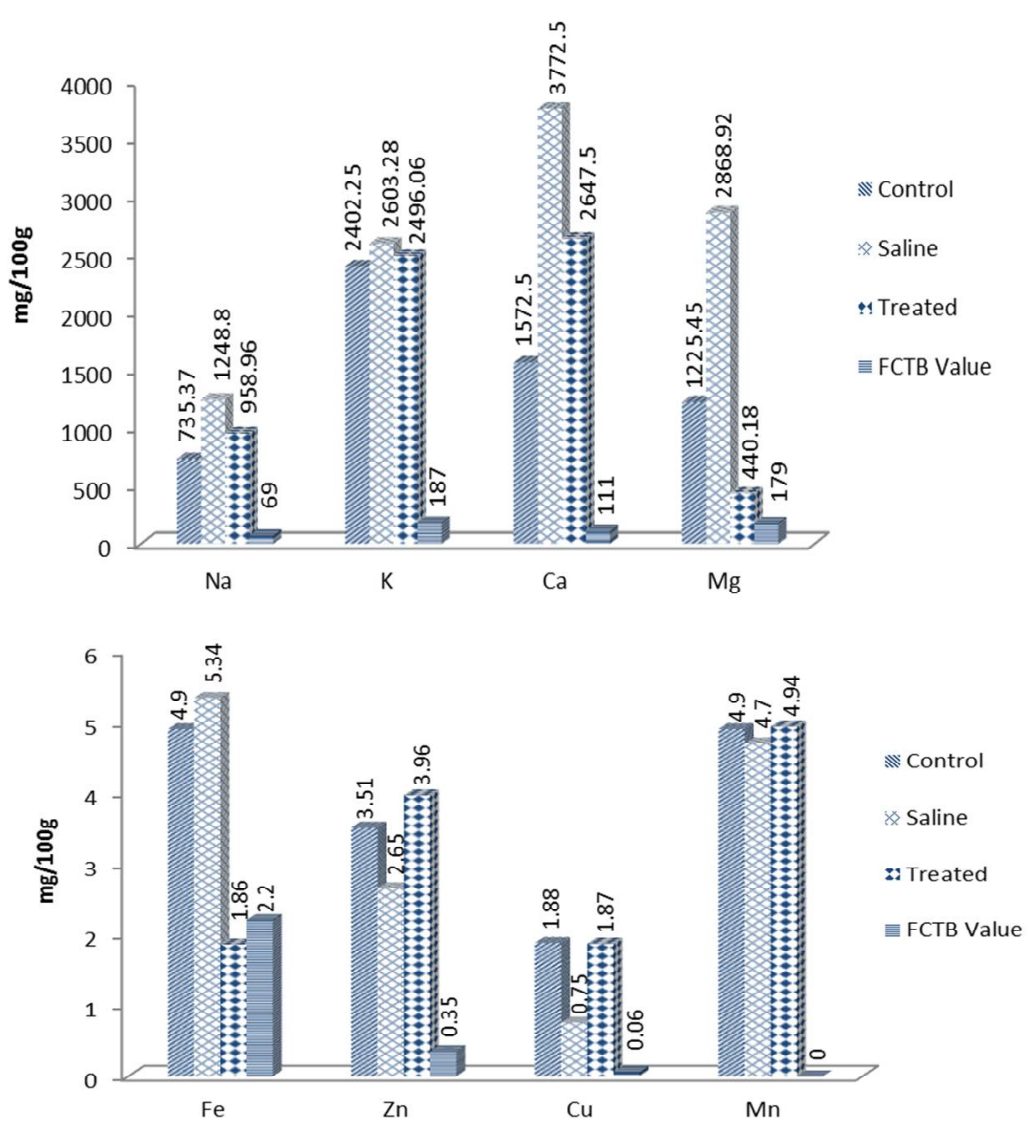

Fig. 3. Mineral contents of Indian spinach in response to various irrigation water applications.

(FCTB 2013). So, it is observed that by irrigating with treated water, $\mathrm{Zn}$ and $\mathrm{Cu}$ contents have increased than the other two water treatments and it is also higher than the standard value. The Mn content was 4.9, 4.7, and $4.94 \mathrm{mg} / 100 \mathrm{~g}$ (Fig. 3). The standard value of 
Mn is not recorded by FCTB (2013). From the value, it can be seen that the Mn content does not vary considerably for all three water treatments.

Effect on post-harvest soil: During investigation, there were no appreciable changes in soil $\mathrm{pH}$ for different treatments, but there was a tendency of raising $\mathrm{pH}$ values by irrigating with saline water. According to Manchanda and Chawla (1981), the $\mathrm{pH}$ of the soil increased after monsoon period when saline water was applied for irrigation.

Changes in electrical conductivity of the post-harvest soil with the application of three different water treatments are shown in Table 3. After harvesting of Indian spinach, EC of the surface soil decreases more $(0.11 \mathrm{dS} / \mathrm{m})$ for treated water than $(0.15 \mathrm{dS} / \mathrm{m})$ for saline water. In sub-surface soil, EC decreases more $(0.13 \mathrm{dS} / \mathrm{m})$ for control water than $(0.15 \mathrm{dS} / \mathrm{m})$ for saline water. The EC values of soil remain at a reasonably low value during the monsoon rains and then gradually increased in dry periods in the coastal saline soils (Clarke et al. 2015). The reasons for decline in EC values with sweet water $(0.11 \mathrm{dS} / \mathrm{m})$ might be due to the washing and percolation of soluble salts from the soil surface and higher EC values due to the accumulation of soluble salts. The results are in close agreement with the findings of Manchanda et al. (1982) who stated that the salt was accumulated in the $0-30 \mathrm{~cm}$ soil depth as a result of the use of highly saline water.

The initial organic matter $(\mathrm{OM})$ value of the surface and sub-surface soil was 1.88 and $1.18 \%$. After harvesting of Indian spinach, OM of the surface soil decreases more $(0.67 \%)$ for treated water and lowest $(1.43 \%)$ for saline water. In the sub-surface soil, OM decreases $(0.58 \%)$ in treated water and increases $(1.27 \%)$ in control water. These results are in close harmony with the findings of Ahmed et al. (1986) who reported that organic matter content of the soil increased when higher levels of saline water was used for irrigation. The increased amount of organic matter in soil was probably due to low decomposition at higher salinity.

After harvesting of Indian spinach, N, P and Ca of the both surface and sub-surface soil, $\mathrm{Mg}$ of the sub-surface soil and $\mathrm{Cu}$ of the surface soil decreased more for saline water. Again $\mathrm{Na}$ and $\mathrm{Fe}$ of the surface and sub-surface soil and $\mathrm{Cu}$ of the sub-surface soil decreased less for saline water. In the treated water plot, $\mathrm{K}, \mathrm{Mg}$ and $\mathrm{Fe}$ of the surface soil and $\mathrm{Na}$ of the both soil decreased more while $\mathrm{N}, \mathrm{S}$ and $\mathrm{Ca}$ of the both soil and $\mathrm{P}$ of the sub-surface soil decreased less. $\mathrm{Zn}$ and $\mathrm{Mn}$ showed a decrease in surface soil and increase in sub-surface soil for saline water and vice versa for treated water. In control water treatment, $\mathrm{K}, \mathrm{Fe}$ and $\mathrm{Cu}$ of the sub-surface soil and $\mathrm{S}$ of the surface and subsurface soil decreased and $\mathrm{P}$ and $\mathrm{Cu}$ of the surface soil and $\mathrm{Mg}$ of both soil increased than other two treatments. 
Table 3. Physico-chemical characteristics of the pre- and post-harvest soil under various irrigation water applications.

\begin{tabular}{|c|c|c|c|c|c|}
\hline \multicolumn{2}{|c|}{ Chemical properties } & \multirow{2}{*}{$\begin{array}{c}\begin{array}{c}\text { Pre-harvest } \\
\text { values }\end{array} \\
7.4\end{array}$} & \multirow{2}{*}{$\begin{array}{c}\begin{array}{c}\text { Post-harvest } \\
\text { values control }\end{array} \\
6.91\end{array}$} & \multirow{2}{*}{$\begin{array}{c}\text { Post-harvest } \\
\text { values saline }\end{array}$} & \multirow{2}{*}{$\begin{array}{c}\begin{array}{c}\text { Post-harvest } \\
\text { values treated }\end{array} \\
7.38\end{array}$} \\
\hline $\mathrm{pH}$ & Surface & & & & \\
\hline & Sub-surface & 7.6 & 7.19 & 7.82 & 7.51 \\
\hline \multirow{2}{*}{$\begin{array}{l}\mathrm{EC} \\
(\mathrm{dS} / \mathrm{m})\end{array}$} & Surface & 0.22 & 0.13 & 0.15 & 0.11 \\
\hline & Sub-surface & 0.17 & 0.13 & 0.15 & 0.14 \\
\hline \multirow[t]{2}{*}{$\mathrm{OM}(\%)$} & Surface & 1.88 & 1.36 & 1.43 & 0.67 \\
\hline & Sub-surface & 1.18 & 1.27 & 0.99 & 0.58 \\
\hline \multirow[t]{2}{*}{$\mathrm{N}(\mathrm{mg} / \mathrm{kg})$} & Surface & 90 & 10 & 8 & 26 \\
\hline & Sub-surface & 105 & 7 & 5 & 30 \\
\hline \multirow[t]{2}{*}{$\mathrm{P}(\mathrm{mg} / \mathrm{kg})$} & Surface & 16 & 10 & 0.4 & 9 \\
\hline & Sub-surface & 0.8 & 0.9 & 0.5 & 2 \\
\hline \multirow{2}{*}{$\begin{array}{l}\mathrm{K} \\
(\%)\end{array}$} & Surface & 7.36 & 6.62 & 7.84 & 6.10 \\
\hline & Sub-surface & 6.83 & 5.87 & 8.88 & 6.84 \\
\hline & Surface & 0.16 & 0.08 & 0.11 & 0.16 \\
\hline & Sub-surface & 0.07 & 0.07 & 0.10 & 0.30 \\
\hline \multirow{2}{*}{$\begin{array}{l}\mathrm{Na} \\
(\%)\end{array}$} & Surface & 12.86 & 11.12 & 12.28 & 9.65 \\
\hline & Sub-surface & 12.06 & 10.42 & 10.76 & 8.49 \\
\hline \multirow{2}{*}{$\begin{array}{l}\mathrm{Ca} \\
(\%)\end{array}$} & Surface & 8.28 & 7.88 & 7.61 & 8.42 \\
\hline & Sub-surface & 8.25 & 7.20 & 6.93 & 9.17 \\
\hline \multirow{2}{*}{$\begin{array}{l}\mathrm{Mg} \\
(\%)\end{array}$} & Surface & 0.78 & 0.81 & 0.64 & 0.61 \\
\hline & Sub-surface & 0.72 & 0.71 & 0.56 & 0.69 \\
\hline \multirow{2}{*}{$\begin{array}{l}\mathrm{Fe} \\
(\%)\end{array}$} & Surface & 0.05 & 0.06 & 0.09 & 0.03 \\
\hline & Sub-surface & 0.05 & 0.03 & 0.06 & 0.04 \\
\hline \multirow{2}{*}{$\begin{array}{l}\mathrm{Zn} \\
(\mathrm{mg} / \mathrm{kg})\end{array}$} & Surface & 104.6 & 21.62 & 5.74 & 25.45 \\
\hline & Sub-surface & 27.56 & 7.64 & 16.83 & 7.47 \\
\hline \multirow{2}{*}{$\begin{array}{l}\mathrm{Cu} \\
(\mathrm{mg} / \mathrm{kg})\end{array}$} & Surface & 160.6 & 96.2 & 82.07 & 92.2 \\
\hline & Sub-surface & 110.0 & 55.2 & 71.8 & 60.67 \\
\hline \multirow{2}{*}{$\begin{array}{l}\mathrm{Mn} \\
(\mathrm{mg} / \mathrm{kg})\end{array}$} & Surface & 772 & 119.8 & 113.6 & 153.93 \\
\hline & Sub-surface & 406 & 139.6 & 145.27 & 138.33 \\
\hline
\end{tabular}

\section{Conclusion}

It may be concluded that the response of treated water irrigation is much better than saline water in relation to nutrient composition (food value) and showed an increased protein, fat, carbohydrate, TDF and energy content in treated water irrigation plants. The 
available $\mathrm{N}, \mathrm{P}, \mathrm{S}, \mathrm{Ca}, \mathrm{Zn}$ and $\mathrm{Mn}$ contents of the soil were increased and $\mathrm{K}, \mathrm{Na}, \mathrm{Mg}$ and $\mathrm{Fe}$ contents decreased substantially that might contribute in higher plant growth and yield. The results demonstrated that the best alternate water source is treated water (MAR water) for better food production as well as good quality crops and nutrition rich food in coastal areas. More cultivable land could be brought under food production using the treated water to improve food security and nutrition status. This study will help the researchers to uncover the potential land use of saline soil and production of crops that cannot tolerate the salt stress.

\section{Acknowledgement}

The authors thank the authority of Managed Aquifer Recharge (MAR) for community water supply in saline areas, Khulna district for supporting to conduct the field experiment and assisting in soil and plant sampling, and finally for their logistic support.

\section{References}

Ahmed, I.U., M.S. Akhan and M. R. Bhuiya, 1986. Grading of brackish water for irrigation and its influence on the change of soil properties associated with crop management (in Bangladesh). In: 11th. Annual Bangladesh Science Conference, Rajshahi (Bangladesh), 2-6 March 1986. BAAS.

Chavan, P.D. and B.A. Karadge. 1980. Influence of salinity on mineral nutrition of Pea-nuts. Plant and Soil 54: 5-13.

Clarke, D., S. Williams, M. Jahiruddin, K. Parks and M. Salehin. 2015. Projections of on-farm salinity in coastal Bangladesh. Environmental Science: Processes and Impacts 17(6): 11271136.

Daryush, T., M. A. Kadir, M. K. Yusop, A. Valdiani and M. P. Abdullah. 2012. Salinity effects on macro and micronutrient uptake in medicinal plant King of Bitters (Andrographis paniculata Nees.). Plant Omics 5(3): 271-278.

Devitt, D., W.M. Jarrel and K.L. Stevens. 1981. Sodium-Potassium ratios in soil solution and plant response under saline conditions. Soil Science Society of America Journal 45: 80- 86.

FCTB (Food Composition Table for Bangladesh). 2013. Institute of Nutrition and Food Science and Centre for Advanced Research in Sciences, University of Dhaka.

Feizi, M., M. A. Hajabbasi and B. Mostafazadeh-Fard. 2010. Saline irrigation water management strategies for better yield of safflower (Carthamus tinctorius L.) in an arid region. Australian Journal of Crop Science 4(6): 408-414.

Francois, L.E., T.J. Donovan and E.V. Mass. 1990. Salinity effects on emergence, vegetative growth and seed yield of guar. Agronomy Journal 82(3): 587-592.

Haque, S.A. 2006. Salinity problem and crop production in coastal regions of Bangladesh. Pakistan Journal of Botany 38(5): 1359-1365. 
Huq, S.M.I. and M.D Alam. 2005. A handbook on analyses of soil, plant and water. BangladeshAustralia Centre for Environmental Research (BACER)-DU, University of Dhaka, Bangladesh.

Karim, Z., S.G. Hussain and M. Ahmed. 1990. Salinity Problems and Crop Intensification in the Coastal Regions of Bangladesh. Soils Publication No. 33. Farmgate, New Airport Road, Dhaka-1215: Bangladesh Agricultural Research Council.

Katerji, N., J.W. van Hoorn, C. Fares, A. Hamdy, M. Mastrorilli and T. Oweis. 2005. Salinity effect on grain quality of two durum wheat varieties differing in salt tolerance. Agricultural Water Management 75(2): 85-91.

Manchanda, H.R. and K.L. Chawla. 1981. Salt profile variations and wheat under irrigation with highly saline waters on coarse loamy soils in south-western Haryana. Journal of Indian Society of Soil Science. 29(4): 504-511.

Manchanda, H.R., S.K. Sharma and D.K. Bhandari. 1982. Response of barley and wheat to phosphorus in the presence of chloride and sulphate salinity. Plant and Soil 66: 233-241.

Raghuramulu, N., N.K. Madhavan and S. Kalyanasundaram. 2003. A Manual of Laboratory Techniques. National Institute of Nutrition. Indian Council of Medical Research, Hyderabad, India.

Rahneshan, Z., F. Nasibi and A. A. Moghadam. 2017. Effects of salinity stress on some growth, physiological, biochemical parameters and nutrients in two pistachio (Pistacia vera L.) rootstocks. Journal of Plant Interactions 13(1): 73-82.

Ullah, S.M., M.H. Gerzabek and G. Soja. 1994. Effect of sea water and soil salinity on ion uptake, osmotic adjustment and quality of tomato (fruit). Bodenkultur. 45(3): 227-237.

Web 1: http://gripp.iwmi.org/natural-infrastructure/water-quality-2/a-nature-based-innovative-andlow-cost-solution-for-disaster-resilient-drinking-water-supply-in-coastal-bangladesh/ 